\title{
The Value of Transferable Skills
}

WP n. ${ }^{0} 2012 / 09$

DOCUMENTO DE TRABALHO WORKING PAPER 


\section{DINAMIR'CET}

2. THE RETURN TO TRANSFERABLE SKILLS ................................................. 3

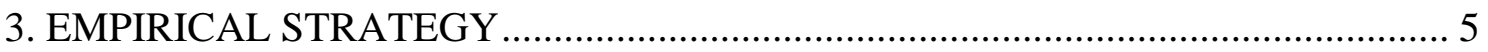

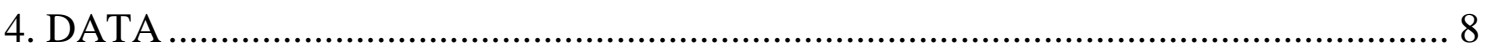

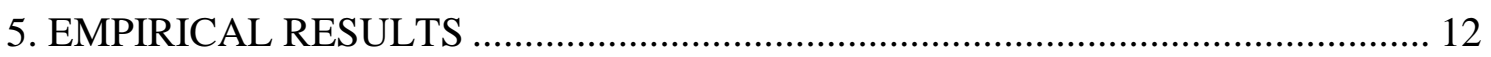

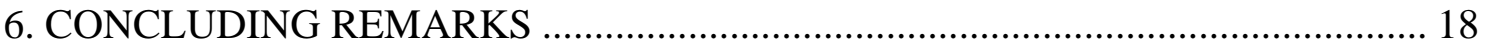

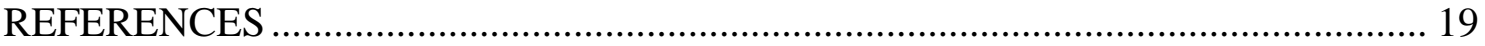




\title{
The Value of Transferable Skills ${ }^{1}$
}

\begin{abstract}
This paper assesses the extent of inter-firm transferability for the skills developed by whitecollar employees in the Portuguese retail banking sector. Assuming that employers will be willing to reward productive skills only, we measure skill transferability as the wage differential between firm switchers and firm stayers. Based on Quadros de Pessoal, a longitudinal archive of linked employer-employee data on the Portuguese labour market, our results support the hypothesis of significant inter-firm and inter-industry skill transferability. Difference-indifferences estimates with propensity score matching show that, on average, firm switchers benefit from a wage premium compared to firm stayers. However, when accounting for the destination sector the observed wage premium quickly drops with the distance from the banking industry.
\end{abstract}

Key words: skill transferability, banking industry, wage, difference-in-differences, propensity score matching.

JEL: J24, J31, J62

\footnotetext{
${ }^{1}$ This paper draws on the research carried out within the Project "FLEX - Flexible wages for flexible contracts? The dynamics of the relationship between wage policy and employment contracts at the firm level" financed by the Fundação para a Ciência e a Tecnologia - FCT, reference PTDC/EGE-ECO/108547/2008.

DINÂMIA'CET - IUL, Centro de Estudos sobre a Mudança Socioeconómica e o Território ISCTE-IUL - Av. das Forças Armadas, 1649-026 Lisboa, PORTUGAL

Tel. 217938638 Fax. 217940042 E-mail: dinamia@iscte.pt http://dinamiacet.iscte-iul.pt/
} 


\section{INTRODUCTION}

Over the past decades, the human capital theory has played an important role in our understanding of wage premia attached to specific types of skills (Becker, 1964). Depending on skill fungibility, the human capital theory discriminates between general skills, useful in virtually all workplaces, and specific skills, required by selected employers only. The opposition between general skills and specific skills provided support to models of the labour market that long affected theoretical and empirical research on wage policies, such as internal labour markets (Doeringer and Piore, 1971) or the signalling theory (Spence, 1973). Nevertheless, the radical opposition between general and specific skills has been repeatedly questioned in more recent years. Since the initial acknowledgement of an intermediate category of transferable skills between firm-specific and general skills (Shaw, 1987; Stevens, 1996), subsequent studies have highlighted the role played by industry-specific skills (Neal, 1995; Parent, 2000), occupationspecific skills (Shaw, 1987; Poletaev and Robinson, 2008; Kambourov and Manovskii, 2009; Zangelidis, 2008; Sullivan, 2010) or task-specific skills (Gathmann and Schönberg, 2007).

This literature supports the existence of sizable, despite heterogeneous, returns to industry-specific experience that significantly overlap and interact with occupation-specific and taskspecific experience. However, the large majority of the studies on skill transferability across firms and industries focus on the return to experience and skills developed in the current job and disregard how the different characteristics of the origin and the destination industries may constrain the transferability of an employee skills and impact on her or his wage. By comparing the return to skills for firm stayers, firm changers in the same industry and firm changers to more distant industries this paper aims at assessing the borders of skill transferability.

The sector-specific empirical analysis provided in this paper focuses on the retail banking industry, highly regulated in the past (Seltzer, 2010; Monteiro, 2009; Seltzer and Frank, 2007; Eriksson and Werwatz, 2005; Seltzer and Merrett, 2000) and more recently exposed to intense institutional, technological and organisational change (Buzzacchi et al., 1995; Hunter et al., 2001; Gelade and Ivery, 2003). The accelerated industrial dynamics, characterised by new entries, mergers and acquisitions, and the digitalisation of labour flows, involving both competence-enhancing and competence-destroying change, emphasise the importance of skill transferability for long-term employability of the labour force in retail banking. In addition, evidence on the return to industry specific skills in retail banking is mixed and calls for further investigation. Kletzer (1996) supports the transferability of the skills developed in finance and services by showing that pre-displacement tenure from these sectors involves a higher return than tenure accumulated in other sectors. On the contrary, Zangelidis (2008) provides evidence in support

DINÂMIA'CET - IUL, Centro de Estudos sobre a Mudança Socioeconómica e o Território ISCTE-IUL - Av. das Forças Armadas, 1649-026 Lisboa, PORTUGAL

Tel. 217938638 Fax. 217940042 E-mail: dinamia@iscte.pt http://dinamiacet.iscte-iul.pt/ 
of skill specificity by reporting banking and finance as the only sector that recognises a significant wage premium for industry-specific experience.

Our empirical analysis is based on Quadros de Pessoal, a longitudinal archive of linked employer-employee data on the Portuguese labour market that allows tracking an employee's career across years and across subsequent employers. With the aim of limiting the variance in skills among the observed employees, hence in wages and career opportunities, we restrict our analysis to white-collar workers. Difference-in-differences estimates with propensity score matching show that, on average, firm switchers benefit from a wage premium compared to firm stayers. However, when accounting for the destination sector the observed wage premium quickly drops with the distance from the banking industry.

The rest of the paper is organised as follows. Section 2 surveys the literature on transferable skills and details our research hypothesis. Section 3 outlines our empirical strategy and section 4 presents the data. Section 5 reports the empirical evidence and section 6 draws our conclusions from this study.

\section{THE RETURN TO TRANSFERABLE SKILLS}

If agreement on the general meaning of transferable skills exists among scholars, significant differences arise when providing an operational definition for this concept. Stevens (1996) defines transferable skills as an intermediate category between general and specific skills whose applicability, despite restricted to a limited cluster of employers, spans beyond the borders of the firm. Sullivan (2010) recalls Becker's dichotomy between completely general and specific skills, yet he discriminates among firm-specific, occupation-specific and industry-specific skills. Kletzer (1996) refers to industry-specific skills as a special form of transferable skills. A transferable nature of skills is suggested also by Lazear's skill-weights approach. All skills have a general nature, yet the special combination of skills required to perform a particular task at a certain workplace turn them into specific skills (Lazear, 2003).

Research on skill transferability across employers has been triggered by the question on whether displaced workers suffer a wage loss when re-entering the labour market. The underlying assumption is that the less transferable the skills provided by an employee, the higher the post-displacement wage loss she or he will experience (Addison and Portugal, 1989). The first attempts to quantify the costs due to the loss of firm-specific skills for displaced workers date back to the late 1980s. The natural set to test the impact of skill transferability on wages was soon recognised in job mobility, especially by means of a direct comparison between industry stayers and industry switchers (Podgursky and Swaim, 1987; Addison and Portugal, 1989; Neal, 1995; Kletzer, 1996). Neal (1995) provides evidence on the higher post-displacement wage 
losses suffered by industry switchers compared to industry stayers. Weinberg (2001) suggests that the recruitment of experienced workers endowed with industry-specific skills is less sensitive to industry shocks than in the case of younger workers. Based on longitudinal datasets, Parent (2000) provides additional evidence on the higher return to industry-specific skills compared to firm-specific skills.

However, other studies argue that a dichotomous contrast between industry stayers and industry switchers cannot provide a full picture of skill transferability across industries (Kletzer, 1996). Movers face a range of alternatives and their final choice is affected by multiple drivers. Pack and Paxson (1999) suggest that physical proximity and similarity in processes and labour flows significantly condition labour mobility patterns. Workers are willing to move to closer industries in order to better exploit their accumulated skills and receive higher wages (Poschl and Foster, 2010). Kletzer (1996) and Cha and Morgan (2010) show that the reward for transferable skills varies with the destination industry. Ong and Mar (1992) report that displaced workers from Silicon Valley companies rehired in the same 4-digit industry display no wage loss, whereas the earnings of those re-employed outside high-tech industries suffer large declines.

In summary, many studies report substantial heterogeneity in the earnings of firm switchers. However, when a heterogeneous effect of the re-employment industry on wages is assumed, measuring this heterogeneity becomes a crucial research target. Kletzer (1996) estimates the wage change between pre-displacement and post-displacement jobs by destination industry and suggests that wages are conditioned by wage patterns in the re-employment industry. In a similar way, Cha and Morgan (2010) show that re-employment in traditional low-wage industries involves a wage loss, whereas Ong and Mar (1992) highlight the need to identify the borders between "close" and "far away" industries in subsequent employment contracts.

Despite the hints offered by the above studies, systematic research on inter-industry distance and its impact on the wage of industry switchers is still missing. A more rigorous use of the metaphor of distance to describe similarity/dissimilarity in transferred skills is provided by studies on occupational mobility (e.g., Poletaev and Robinson, 2008; Kambourov and Manovskii, 2008). The measure of distance between subsequent occupations is based on comparing the occupation-specific tasks and skills listed by occupation directories such as the U.S. Dictionary of Occupational Titles. This approach allows for direct and quantitative comparisons between all possible pairs of occupations, provided that they are described in the same occupation directory. However, the heavy reliance upon the chosen classification tool (i.e., the occupation directory) limits the extension of this approach to other levels of analysis such as the industry level. 
To test the borders of skill transferability from the banking industry we will assess the relative wage premium (or wage loss) of firm movers who find a new job in industries progressively more far away from their source industry. The underlying assumption is that highly firmspecific skills have no value outside the workplace where they developed and no external employer is expected to pay for them. On the contrary, fully transferable general skills are expected to be acknowledged and rewarded by any employer outside the source firm. In case of partial skill transferability, non-negative returns can be expected when the old and the new employer make use of similar technologies, procedures and tools. Our research hypothesis is that industry matters in the transferability of firm switchers' skills. The larger the distance between the industries of source and destination employer, the higher the share of lost skills and consequently the lower the return to transferable skills.

\section{EMPIRICAL STRATEGY}

The return to skill transferability across different firms and different industries is usually tested by estimating the relationship between job mobility and wage mobility. For instance, Parent (2000) assesses the return to tenure with the current employer and experience in the current industry, whereas Neal (1995) provides separate estimates of the return to pre-displacement tenure for displaced employees who either find a new job in their original industry or move to a different sector. Those approaches provide evidence on the benefits of accumulating firmspecific skills (Neal, 1995) and industry-specific skills (Parent, 2000) when remaining in the same sector. However, they do not allow assessing the borders of skill transferability, i.e., how far an employee can move from the original workplace before her or his skills loose value for potential employers.

Equation (1) shows a simple model for testing the limits of skill transferability. $\square_{\mathrm{it}}$ is the wage received by employee $\mathrm{i}$ at time t, $\overline{M_{i t}}=\left\{M_{1, i t}, M_{2, i t}, \ldots, M_{H, i t}\right\}$ is a vector of $\mathrm{H}$ binary

variables accounting for recent employer and industry change, $\bar{Z}_{i t}$ is a vector of control variables and $\varepsilon_{i t}$ is the error term.

$$
\ln \omega_{i t}=\beta_{0}+\overline{M_{i t}} \overline{\beta_{1}}+\bar{Z}_{i t} \overline{\beta_{2}}+\varepsilon_{i t}
$$

A significant and positive (negative) coefficient for a generic move $\mathrm{M}_{\mathrm{h}, \mathrm{t}}$ signals a wage premium (wage loss) for movers to a new employer in industry h compared to the reference category of firm stayers, whereas a non-significant coefficient reflects the lack of statistical differences between movers and stayers. 
Nevertheless, the estimate of equation (1) presents substantial empirical challenges. First, the choice of moving to a different employer and, possibly, to a different industry is endogenous with wage after change (Kletzer, 1996). The active search for a better employer-employee match or the deterioration of individual productivity in the new workplace due to a poor match may explain both job mobility and earnings in the new job. Instrumental variables are often used to overcome the potential biases due to the presence of endogenous explanatory variables (see, e.g., Parent, 2000). However, the identification of suitable instruments for all the binary variables that account for possible moves to new employers and new industries in equation (1) looks particularly challenging.

Propensity Score Matching (PSM) provides an alternative approach to identify the average impact of job mobility for firm switchers compared to firm stayers. The core idea of PSM, originally developed to assess the causal effects of policy measures in natural experiments ${ }^{2}$, is that comparison between a set of treated individuals and a control group should be based on individuals as similar as possible along a set of pre-treatment characteristics $\mathrm{X}$ affecting both the observed outcome and the probability of selecting into the treatment. A matching mechanism rules out systematic differences between treated and untreated individuals and allows for an unbiased estimate of the average treatment on the treated. Matching algorithms are based on a balancing score $b(X)$, i.e., a function of the pre-treatment observable variables $X$ such that the conditional distribution of $\mathrm{X}$ given $\mathrm{b}(\mathrm{X})$ is the same for treated and control individuals (Conditional Independence Assumption). The computational difficulty of matching similar individuals increases with the dimension of vector X. However, Rosenbaum and Rubin (1983) proved that conditional independence is still valid if controlling for the probability of participation based on the X covariates, instead on vector X. Lechner (2001) extends Rosenbaum and Rubin's findings to the case of multi-level treatments and proposes a four-step procedure for a matching estimator of treatment effects. An empirical implementation of the suggested estimator is provided by Larsson (2003) in the case of active labour market programmes for young Swedish workers ${ }^{3}$.

Despite providing an appealing answer to the problem of assessing the impact of an endogenous employer change on wage, PSM suffers from significant limitations. The conditional independence assumption requires the probability of participation to be captured by pretreatment observable variables $\mathrm{X}$, a condition hardly met in case of unobservable individual heterogeneity. In addition, PSM does not account for possible time trends unrelated with the treatment. When information on output is available for treated individuals and for the control

\footnotetext{
${ }^{2}$ For recent surveys, see Caliendo and Kopeinig (2008) and Imbens and Wooldridge (2009).

${ }^{3}$ Additional applications of PSM with multi-level treatment are provided by Dorsett (2006), who assesses the impact of four programmes of subsidised fixed-term employment and training promoted by the UK government on the probability of job entry and by Davia (2010), who measures the wage impact of different types of job mobility on the early career of Spanish workers.
} 
group both before and after the former are exposed to the treatment, those problems can be solved by a difference-in-differences (DID) approach. In DID estimates the average gain in output for the treated after and before the treatment is compared to the average gain enjoyed by the control group in the same time period. The double differentiation - across groups and across time - accounts for both unobserved time-invariant differences between treated and untreated individuals and for time trends independent of the considered treatment (Imbens and Wooldridge, 2009).

Nevertheless, also the applicability of DID estimators is limited by strong constraints. DID estimators assume that in case of no treatment the average outcome of treated individuals would have followed the same time trend observed for the control group, irrespective of possible unbalance in the distribution of pre-treatment characteristics affecting the output of treated and untreated individuals (Abadie, 2005). The combination of propensity score matching with difference-in-differences methods (PSM-DID) consequently provides a promising solution to account for both unobserved heterogeneity, treatment-independent time trends and unbalanced distribution of pre-treatment characteristics associated with the observed outcome among individuals in treated and control groups (Heckman et al., 1997; Blundell and Costa Dias, 2000; Imbens and Wooldridge, 2009). The recent surge of empirical applications of PSM-DID estimators in the areas of labour economics and education economics confirms the potentiality of those tools to solve problems of selection on observables and independent time trends ${ }^{4}$. However, with the notable exception of Davia (2010), the existing contributions focus on binary treatments and neglect the multi-level case, apt for modelling the multiple alternatives available to a firm/industry switcher.

A convenient semi-parametric estimator for testing the average treatment on the treated in case of multi-level treatment is provided by Abadie (2005). Consider a multi-level treatment consisting in $\mathrm{H}$ mutually exclusive levels and a two time periods set. No individual is exposed to any treatment in the first period, whereas the unconditional probability of being exposed to treatment $\mathrm{h}$ in the second period is equal to $\mathrm{P}(\mathrm{H}=\mathrm{h})$. For each treatment level, $\mathrm{Y}_{\mathrm{t}}(1)$ represents the outcome observed for individuals exposed to that treatment at time $t$, while $Y_{t}(0)$ is the counterfactual outcome. As no individual is treated in the first time period, $\mathrm{Y}_{0}(0)=\mathrm{Y}_{0}(1) \forall \mathrm{h} \in \mathrm{H}$. Under the conditional independence assumption

$$
E\left[Y_{1}(0)-Y_{0}(0) \mid X, H\right]=E\left[Y_{1}(0)-Y_{0}(0) \mid X\right]
$$

and the overlap assumption that the support of the propensity score for the treated is a subset of the propensity score for the untreated, Abadie (2005) shows that the average treatment on the

\footnotetext{
${ }^{4}$ See, e.g., Blundell et al. (2004), Bergemann et al. (2009), Leombruni et al. (2010), Buscha et al. (2012).

DINÂMIA'CET - IUL, Centro de Estudos sobre a Mudança Socioeconómica e o Território

ISCTE-IUL - Av. das Forças Armadas, 1649-026 Lisboa, PORTUGAL

Tel. 217938638 Fax. 217940042 E-mail: dinamia@iscte.pt http://dinamiacet.iscte-iul.pt/
} 
treated for treatment level $\mathrm{h}$ compared to the counterfactual of untreated individuals ${ }^{5}$ can be modelled as

$$
\tau_{A T T}=E\left\{\frac{\left(Y_{1}-Y_{0}\right)}{P(H=h)} *\left(h-h_{0} * \frac{P(H=h \mid X)}{1-\sum_{j \in H} P(H=j \mid X)}\right)\right\}
$$

In equation (3), $Y_{1}$ and $Y_{0}$ are the outcomes observed for the same individual in two subsequent time periods; $\mathrm{h}$ is a binary variable equal to 1 if the observed individual is exposed to treatment $\mathrm{H}$ at level $\mathrm{h} ; \mathrm{h}_{0}$ is a binary variable equal to 1 if the observed individual is exposed to no treatment; $P(H=h \mid X)$ is the individual propensity score for treatment level h given a set of X covariates; and $1-\sum_{j \in H} P(H=j \mid X)$ is the individual propensity score for no treatment.

A consistent and $\sqrt{N}$-asymptotically normal estimator of the average treatment on the treated for treatment level $\mathrm{h}$ can be consequently calculated as in (4)

$$
\hat{\tau}_{A T T}=\frac{1}{N} \sum_{k=1}^{N}\left\{\frac{\left(Y_{1}-Y_{0}\right)}{P(H=h)} *\left(h-h_{0} * \frac{\hat{P}(H=h \mid X)}{1-\sum_{j \in H} \hat{P}(H=j \mid X)}\right)\right\}
$$

where $\mathrm{N}$ is the number of individuals either in treatment level $\mathrm{h}$ or in no treatment. In case of binary treatment, the estimator in (4) can be re-written as

$$
\hat{\tau}_{A T T}=\frac{1}{N} \sum_{k=1}^{N}\left\{\frac{\left(Y_{1}-Y_{0}\right)}{P(D=1)} * \frac{D-\hat{P}(D=1 \mid X)}{1-\hat{P}(D=1 \mid X)}\right\}
$$

where $\mathrm{D}$ is equal to 1 for individuals exposed to treatment.

The estimator proposed by Abadie (2005) presents important advantages over other PSM-DID estimators (e.g., Heckman et al., 1997; Blundell and Costa Dias, 2000). As the distribution of covariates is balanced between treated and untreated by simply weighting untreated observations through their covariate-based propensity scores, Abadie's parsimonious estimator requires no additional hypothesis on the matching mechanism. In addition, the extension to the multi-level case makes this estimator suitable for testing the wage effect of moving to a different employer and possibly a range of different industries compared to a counterfactual sample of firm stayers.

\section{DATA}

The data used in the empirical assessment of the boundaries of skill transferability from the Portuguese banking industry are provided by Quadros de Pessoal, a longitudinal dataset that includes the population of Portuguese firms with at least one wage earner and their employees in manufacturing and services private sectors ${ }^{6}$. Thanks to unique employer and employee codes,

\footnotetext{
${ }^{5}$ It has to be noted that if the participants in two treatments differ in a non-random fashion, the average treatment on the treated will not be symmetric (Lechner, 2001).

${ }^{6}$ Data are collected annually by the Portuguese Ministry of Employment. For additional details, see Cardoso and Portugal (2005) and Mamede (2006).
} 
Quadros de Pessoal allows matching employer and employee information and mapping employees' careers in time across subsequent employers.

The identification of retail banking firms is based on a 3-digit industry code and includes all companies listed in the area of monetary intermediation ${ }^{7}$. For the purpose of the following analysis, we included in our sample full-time permanent white-collars employed at least once at a Portuguese retail bank between 2002 and 2008 and still in employment one year later, either with the same employer or with another firm. To avoid an over-representation of firmstayers, we focused on the most recent observation reported for all unique employees.

Wage dynamics is significantly affected by the phase of the working life cycle. Career opportunities decrease with age due to the lower number of available positions at higher hierarchical levels and to decelerated learning processes, possibly coupled with skill obsolescence. In addition, higher mobility costs and shorter time horizons to cushion those costs reduce the propensity to firm change by older employees. The choice to select the most recent observation of banking employees between 2002 and 2008 may consequently generate an over-representation of elderly individuals characterised by slower wage dynamics. To avoid possible biases due to the approaching of retirement from the labour market, we discarded observations concerning individuals above 55 years of age. In addition, we removed observations on $1.5 \%$ top and bottom earners by 1-digit occupation and observations with missing information on wage, working hours or job. The resulting database includes 47,275 observations from 124 banking firms, 5,094 of them concerning firm switchers.

Quadros de Pessoal provides no information about the reasons behind the interruption of an employment contract. Consequently, we are not able to discriminate between voluntary and involuntary leaves. However, employer records by Quadros de Pessoal confirm that no Portuguese banking firm closed down between 2002 and 2009 and no massive layoffs are recorded in the same period. By examining employer records we detected 13 acquisitions where at least $90 \%$ of the workforce of the acquired company was absorbed by the buying company without interruption of tenure tracks. All mergers and acquisitions in the Portuguese banking industry in the first decade of this century were accompanied by negotiations with trade unions aimed at protecting employment levels (Esteves, 2008; Silva, 2009). We can therefore exclude involuntary firm changes due to bank mergers. Still, we cannot exclude that a share of firm changers left their full-time permanent position involuntary, after breaking discipline or other contract

\footnotetext{
7 Banking firms whose activity classification code changed between 2002 and 2009 were excluded from the analysis, as well as banks where no labour outflows to other firms were recorded in the same period. Due to significant differences in mission and strategy compared to retail banking firms, we also excluded observations from the Portuguese central bank. Quadros de Pessoal records 50,257 unique individuals employed at least once in a full-time permanent white-collar job at the selected retail banking firms between 2002 and 2008.
} 
rules. However, involuntary leaves are reported to represent a marginal share of total leaves in the Portuguese banking industry (BTE, 2005; Esteves, 2008).

To assess the return to inter-firm mobility, an employer change can be framed as a treatment, whereas firm stayers provide the control group. Firm switch corresponds to a multilevel treatment, as an employee could either sign a new contract with another banking firm or move to a different industry.

Measuring the distance between destination industries and the banking sector is crucial for testing our hypothesis of inter-industry skill transferability. Based on the employer industry codes provided by Quadros de Pessoal ${ }^{8}$ we classified firm switchers to other companies in the area of monetary intermediation (same 3-digit industry as the source firm) as moves within the retail banking industry. Employer changes to the areas of "Activities of holding companies", "Trusts, funds and similar financial entities", "Other financial service activities, except insurance and pension funding", "Insurance, reinsurance and pension funding, except compulsory social security", "Legal and accounting activities", "Activities of head offices and management consultancy activities" and "Office administrative and support activities" were classified as moves to firms providing financial services. All other employer changes were classified in the residual categories of moves outside the financial industry.

Table 1 displays the observed job transitions from the banking industry by initial job. The persistence of internal labour markets at Portuguese retail banks is witnessed by the large prevalence of firm stayers compared to firm changers ${ }^{9}$. Over $89 \%$ of observed employees experienced no firm change between 2002 and 2009. Moves to a different employer are slightly more frequent among employees with higher hierarchical positions (managers and professionals), who also display a higher than average propensity to move outside the financial sector.

Tables 2 and 3 provide some preliminary evidence on wage premium and wage losses associated with different types of employment mobility. Table 2 shows that, on average, the wage of firm switchers in their former job is significantly lower than the wage of firm stayers. However, the more substantial wage increase they benefit when moving to a different employer provides them with higher wages at their new employer, compared to firm stayers. Table 3 provides separate comparisons for wage levels and wage growth experienced by firm switchers by destination industry. Despite not accounting for possible structural differences in the distribution of characteristics that affect both the decision to move to another employer and wage levels and differentials, the figures in Table 3 support the intuition that firm switchers are a rather het-

\footnotetext{
${ }^{8}$ Quadros de Pessoal follows the 5-digit industry classification adopted by the Portuguese National Institute of Statistics (CAE, Classificação das Atividades Económicas).

${ }^{9}$ Internal labour markets influence workers' quit decisions (Fairris, 2004). Careers based on long job ladders, systematic pay growth from lower to higher ranks and seniority-based pay tend to discourage job separations.
} 
erogeneous group and that a comparison limited to firm stayers and firm switchers may hamper the identification of more articulated dynamics. If employees who move to other banking firms start from the highest average wage gap and enjoy the highest average premium, gains are smaller when bank white-collars move to less closely related industries. This preliminary evidence supports the hypothesis of declining returns to skills for employees who leave their original industry and justifies the implementation of more sophisticated tools of analysis.

Table 1. Observed job transitions from the retail banking industry

\begin{tabular}{llccccc}
\hline \multicolumn{1}{c}{ Treatment level } & & $\begin{array}{c}\text { Firm } \\
\text { stayers }\end{array}$ & \multicolumn{2}{c}{ Firm changers } & Total \\
Job in first time period & & & $\begin{array}{c}\text { Move to } \\
\text { banking }\end{array}$ & $\begin{array}{c}\text { Move to } \\
\text { finance }\end{array}$ & $\begin{array}{c}\text { Move } \\
\text { outside } \\
\text { finance }\end{array}$ \\
\hline Manager & $\mathrm{N}^{\circ}$ obs. & 3,408 & 262 & 113 & 86 & 3,869 \\
& $\%$ & $88.1 \%$ & $6.8 \%$ & $2.9 \%$ & $2.2 \%$ & $100.0 \%$ \\
Professional & $\mathrm{N}^{\circ}$ obs. & 1,023 & 57 & 19 & 45 & 1,144 \\
Technician & $\%$ & $89.4 \%$ & $5.0 \%$ & $1.7 \%$ & $3.9 \%$ & $100.0 \%$ \\
& $\mathrm{~N}^{\circ}$ obs. & 15,055 & 1,293 & 235 & 284 & 16,867 \\
Clerk & $\%$ & $89.3 \%$ & $7.7 \%$ & $1.4 \%$ & $1.7 \%$ & $100.0 \%$ \\
& $\mathrm{~N}^{\circ}$ obs. & 22,689 & 1,998 & 428 & 264 & 25,379 \\
& $\%$ & $89.4 \%$ & $7.9 \%$ & $1.7 \%$ & $1.0 \%$ & $100.0 \%$ \\
\hline Total & $\mathrm{N}^{\circ}$ obs. & 42,181 & 3,610 & 795 & 689 & 47,275 \\
& $\%$ & $89.2 \%$ & $7.6 \%$ & $1.7 \%$ & $1.5 \%$ & $100.0 \%$ \\
\hline
\end{tabular}

Table 2. Wage differentials between firm stayers and firm switchers

\begin{tabular}{|c|c|c|c|c|c|c|c|c|}
\hline & \multirow{2}{*}{$\begin{array}{l}\text { Firm } \\
\text { changer }\end{array}$} & \multirow{2}{*}{$\mathrm{N}$} & \multirow[b]{2}{*}{$\mu$} & \multirow[b]{2}{*}{$\sigma$} & \multirow{2}{*}{$\begin{array}{l}\text { Std. Error } \\
\text { Mean }\end{array}$} & \multicolumn{3}{|c|}{ t-test for equality of means } \\
\hline & & & & & & $\mathrm{t}$ & d.f. & \\
\hline \multirow[t]{2}{*}{ Total hourly wage in $\mathrm{t}_{0}$} & No & 42,181 & 14.49 & 6.74 & 0.033 & 10.226 & 6692.887 & $* * *$ \\
\hline & Yes & 5,094 & 13.55 & 6.10 & 0.085 & & & \\
\hline \multirow[t]{2}{*}{ Total hourly wage in $t_{1}$} & No & 42,181 & 15.08 & 7.38 & 0.035 & -8.056 & 6695.872 & $* * *$ \\
\hline & Yes & 5,094 & 15.89 & 6.68 & 0.093 & & & \\
\hline \multirow{2}{*}{$\begin{array}{l}\Delta \text { Total hourly wage } \\
\text { between } \mathrm{t}_{0} \text { and } \mathrm{t}_{1}\end{array}$} & No & 42,181 & 0.59 & 2.15 & 0.010 & -36.378 & 5618.567 & $* * *$ \\
\hline & Yes & 5,094 & 2.34 & 3.34 & 0.046 & & & \\
\hline
\end{tabular}

Table 3. Wage differentials by destination industry

\begin{tabular}{|c|c|c|c|c|c|c|c|c|c|}
\hline \multirow[b]{2}{*}{ ANOVA F-test } & \multicolumn{3}{|c|}{ Total hourly wage in $t_{0}$} & \multicolumn{3}{|c|}{ Total hourly wage in $t_{1}$} & \multicolumn{3}{|c|}{$\Delta$ Total hourly wage } \\
\hline & 42.936 & $* * *$ & & 26.374 & $* * *$ & & 1134.937 & $* * *$ & \\
\hline Games-Howell test for multiple comparisons & $\begin{array}{c}\text { Mean } \\
\text { difference }\end{array}$ & $\begin{array}{l}\text { Std. } \\
\text { Error }\end{array}$ & & $\begin{array}{c}\text { Mean } \\
\text { difference }\end{array}$ & $\begin{array}{l}\text { Std. } \\
\text { Error }\end{array}$ & & $\begin{array}{c}\text { Mean } \\
\text { difference }\end{array}$ & $\begin{array}{l}\text { Std. } \\
\text { Error }\end{array}$ & \\
\hline Move to banking vs. Firm stayer & -1.265 & 0.101 & $* * *$ & 1.044 & .107 & $* * *$ & 2.309 & 0.049 & $* * *$ \\
\hline Move to finance vs. Firm stayer & -0.621 & 0.236 & $* *$ & -0.342 & .252 & & 0.280 & 0.108 & $* *$ \\
\hline Move outside finance vs. Firm stayer & 0.422 & 0.274 & & 0.888 & .335 & $* *$ & 0.466 & 0.179 & $* *$ \\
\hline
\end{tabular}

Deflated gross hourly wages ( $€$, base $=1992) ; * * * p<0.01 * * p<0.05 * p<0.10$ 


\section{EMPIRICAL RESULTS}

Following Abadie (2005), the empirical analysis to test the return to firm and industry mobility from the Portuguese banking industry develops along two steps. The first step concerns the calculation of the propensity score to select into firm mobility. The second step involves the estimation of the average wage increase for mobile employees compared with a counterfactual of firm stayers. Both steps are replicated in case of binary treatment, when firm switchers are compared with firm stayers irrespective of their destination industry, and in case of multi-level treatment, when the analysis is detailed for movers to other retail banks, movers to the finance industry and movers outside the finance industry.

Propensity score matching provides reliable results as long as the balancing score actually captures the probability of participation into a treatment. The rich set of pre-treatment observable covariates provided by Quadros de Pessoal enhances the chance of controlling for the factors affecting the probability of receiving a treatment and achieving the observed outcome. Definition and descriptive statistics for those covariates are provided in Table 4 for both the binary and the multi-level treatment.

The coefficients of the binary logistic model used to calculate the propensity score to participate in the binary treatment of moving to a new employer are reported in Table 5. The model displays a satisfactory prediction power, with $92 \%$ of cases correctly classified and a Nagelkerke R-Square of 0.568 . All coefficients are in line with the results from the past literature. Inter-firm mobility increases with educational qualifications and decreases with tenure, age at the time of recruitment by the initial employer and firm size. Female employees display lower mobility compared to their male colleagues and the propensity to move to a new firm is significantly stronger among employees with higher hierarchical positions. Due to the concentration of value-added services in the metropolitan area of Lisbon that characterises the Portuguese economy, we also control for the geographical location of the employer in the first period of time. The more favourable employment opportunities provided by the district of Lisbon, that accounts for $46.3 \%$ of total observations and $56.2 \%$ of firm switchers, are a highly significant determinant of firm change (Table 5). An additional covariate is based on the evidence that workers are sensitive to their income rank in a group of peers (Boyce et al., 2010). The dissatisfaction generated by a lower income compared to other employees in a similar job could trigger search processes aimed at improving the individual perception of income rank. The logarithmic difference between wage in the first time period and the average wage of other employees classified in the same 6-digit job code provided an additional significant determinant of firm switch ${ }^{10}$ ( $\mathrm{Ln}$ dwage peers in Table 5). As expected, the higher the wage differential with peers in the same

\footnotetext{
${ }^{10}$ We verified that at least 20 observations were recorded in Quadros de Pessoal for each 6-digit job code. 
job, the higher the probability of moving to another employer within one year. Eventually, the binary logistic regression controls for fixed year effects and for the collective labour agreement in force at the initial employer. Both year controls and labour agreement controls are jointly significant determinants of the probability to select into a binary treatment.

Table 4. Variables driving selection into treatment

\begin{tabular}{|c|c|c|c|c|c|}
\hline Covariate & Description & $\mu$ & $\sigma$ & $\begin{array}{c}\text { Binary } \\
\text { treatment }\end{array}$ & $\begin{array}{c}\text { Multi-level } \\
\text { treatment }\end{array}$ \\
\hline Tenure t0 & Tenure before treatment [years] & 10.638 & 8.047 & $\mathrm{X}$ & \\
\hline Squared tenure t0 & Squared tenure before treatment & 177.903 & 234.652 & $\mathrm{X}$ & \\
\hline Education years to & Education before treatment [years] & 13.665 & 2.885 & $\mathrm{X}$ & \\
\hline Age hire to & Age at recruitment before treatment [years] & 29.075 & 7.002 & $\mathrm{X}$ & \\
\hline Ln firm size t0 & $\begin{array}{l}\text { Natural logarithm of firm size (employees) before } \\
\text { treatment }\end{array}$ & 7.983 & 1.491 & $\mathrm{X}$ & \\
\hline Ln dwage peers & $\begin{array}{l}\text { Natural logarithm of the difference between individ- } \\
\text { ual yearly gross wage before treatment (euros. } \\
\text { base=1992) and the average wage of other employees } \\
\text { in the same 6-digit job code }\end{array}$ & -0.032 & 0.251 & $\mathrm{X}$ & \\
\hline Turnover t0 & $\begin{array}{l}\text { Employment growth rate at the initial employer } \\
\text { before treatment }\end{array}$ & 0.550 & 0.142 & & $\mathrm{X}$ \\
\hline \multirow[t]{2}{*}{ Attractiveness } & $\begin{array}{l}\text { Differential employment growth rate between desti- } \\
\text { nation and source industry before treatment }\end{array}$ & 0.005 & 0.051 & & $\mathrm{X}$ \\
\hline & & \multicolumn{2}{|l|}{$[\%]$} & & \\
\hline Gender & Takes value 1 for female employees & \multicolumn{2}{|l|}{40.53} & $\mathrm{X}$ & $\mathrm{X}$ \\
\hline Lisbon & $\begin{array}{l}\text { Takes value } 1 \text { for employer location before treatment } \\
\text { in the district of Lisbon }\end{array}$ & \multicolumn{2}{|l|}{46.28} & $\mathrm{X}$ & $\mathrm{X}$ \\
\hline Top manager $t 0^{\circ}$ & Takes value 1 for top managers before treatment. & \multicolumn{2}{|l|}{16.45} & $\mathrm{X}$ & $\mathrm{X}$ \\
\hline Manager t0 & Takes value 1 for managers before treatment. & \multicolumn{2}{|l|}{19.43} & $\mathrm{X}$ & $\mathrm{X}$ \\
\hline Supervisor t0 & Takes value 1 for supervisors before treatment & \multicolumn{2}{|l|}{3.48} & $\mathrm{X}$ & $\mathrm{X}$ \\
\hline Professional t0 & $\begin{array}{l}\text { Takes value } 1 \text { for professional occupations before } \\
\text { treatment }\end{array}$ & \multicolumn{2}{|l|}{21.25} & $\mathrm{X}$ & $\mathrm{X}$ \\
\hline Qualified to & $\begin{array}{l}\text { Takes value } 1 \text { for qualified occupations before treat- } \\
\text { ment }\end{array}$ & \multicolumn{2}{|l|}{28.79} & $\mathrm{X}$ & $\mathrm{X}$ \\
\hline Semiqualified t0 & $\begin{array}{l}\text { Takes value } 1 \text { for semi-qualified occupations before } \\
\text { treatment }\end{array}$ & \multicolumn{2}{|l|}{10.60} & $\mathrm{X}$ & $\mathrm{X}$ \\
\hline
\end{tabular}

42.175 observations; ${ }^{\circ}$ Job reference category in econometric estimates 
Table 5. The drivers of propensity to firm change

\begin{tabular}{|c|c|c|c|}
\hline & $\beta$ & Std. error & \\
\hline Constant & -1.175 & 0.282 & $* * *$ \\
\hline Tenure t0 & -0.059 & 0.010 & $* * *$ \\
\hline Squared tenure t0 & -0.004 & 0.000 & $* * *$ \\
\hline Education years t0 & 0.027 & 0.008 & $* * *$ \\
\hline Age hire t0 & -0.106 & 0.004 & $* * *$ \\
\hline Ln firm size t0 & -0.091 & 0.019 & $* * *$ \\
\hline Ln dwage peers & 0.171 & 0.086 & $* *$ \\
\hline Gender $^{(a)}$ & -0.261 & 0.044 & $* * *$ \\
\hline Lisbon t0 & 0.253 & 0.042 & $* * *$ \\
\hline Manager $\mathrm{t} 0^{(\mathrm{b})}$ & 0.027 & 0.073 & \\
\hline Supervisor $\mathrm{t} 0^{(\mathrm{b})}$ & -0.177 & 0.132 & \\
\hline Professional $\mathrm{t}^{(\mathrm{b})}$ & 0.080 & 0.068 & \\
\hline Qualified $\mathrm{t} 0^{(\mathrm{b})}$ & -0.287 & 0.072 & $* * *$ \\
\hline Semiqualified $t 0^{(b)}$ & -0.311 & 0.121 & $* * *$ \\
\hline-2 Log likelihood & 16.633 .32 & & \\
\hline Nagelkerke R Square & 0.568 & & \\
\hline
\end{tabular}

Regression includes 6 binary controls for two-year periods and 4 binary controls for collective labour agreements (a) Reference category: male employees. (b)Reference category: Top managers

The propensity score for multi-level treatment is calculated through a multinomial logistic regression where the reference category is represented by firm stayers as opposed to moving to another banking firm, moving to a firm in the financial industry and moving to a firm in other industries (Table 6). Compared to the binomial regression, the multinomial analysis includes two additional pre-treatment variables aimed at discriminating among the different destinations of firm switchers. The first variable measures the net labour turnover at the initial employer in the first time period (Turnover t0). High turnover rates are expected to signal uncertainty about future working conditions and to encourage active job search in the external labour market. This variable is a significant predictor of the propensity to move to another employer, but only in the case of moves to firms in the finance industry. An additional variable accounts for the relative attractiveness of the destination industry compared to the source one. Attractiveness is calculated as the difference in yearly employment growth rates between the destination industry and the banking industry ${ }^{11}$. The high value and the strong significance displayed by those coefficients in the multinomial model confirm the importance of employment growth at the industry level as a predictor of the destination industry (Kletzer, 1996).

\footnotetext{
${ }^{11}$ Relative attractiveness is calculated at the 3-digit level for the finance industry and at the 2-digit level for other sectors. The value of this variable is obviously null for movers to other banking firms, whereas mean values are 0.204 and 0.058 , respectively, for movers to the finance industry and movers outside the finance industry.
} 
Also the multinomial logistic regression explains a high percentage of variance in the data (Nagelkerke pseudo R-Square is equal to 0.590) and displays a satisfactory classification power (Table 7). The percentage of correctly classified cases ranges from $97.8 \%$ for firm stayers, to $41.9 \%$ for movers to other firms in the banking sector, to $68.8 \%$ for movers to the finance industry, to $16.8 \%$ for movers outside the finance industry ${ }^{12}$.

The multinomial logistic model "breaks up" the category of firm switchers into three distinct sub-groups. The use of this model is thus reliable as far as the assumption of the independence of irrelevant alternatives is respected (Larsson, 2003). The comparison between the coefficients of the multinomial model and the coefficients of three separate binomial regressions restricted to firm stayers and movers to other banking firms, financial firms and other firms, respectively, did not point out dramatic differences. The assumption of the independence of irrelevant alternatives can thus be regarded as valid. In addition. calculated propensity scores meet the overlap assumption, i.e., $0<P(H=h \mid X)<1 \forall h \epsilon H$.

The exam of the coefficients of the multinomial regression reveals interesting differences among firm switchers by destination industry. First, the differential between the employment growth rate in the destination industry and in the banking sector is a powerful driver of the propensity to leave the banking industry (see the coefficient of variable Attractiveness in Table 6). A $1 \%$ increase in this differential rises by $39 \%$ the odds of moving to the financial sector compared to the odds of remaining with the same employer and increases by $33 \%$ the odds of moving outside banking and financial firms. Contrary to industry attractiveness, recent turnover at the source firm raises the propensity of moving to another firm only when the new employer operates in the financial sector.

In line with the past literature, higher initial tenure and higher recruitment age with the original employer negatively affect the propensity to move to a different firm. Interestingly enough, an initial low ranking in the wage distribution of peers in the same job significantly increases the propensity to change employers, but only for workers who move to another retail bank (see the coefficient of variable Ln dwage peers in Table 6). This outcome suggests that employees who feel under-appreciated may look for a similar workplace to get a better reward for their skills and capabilities. On the contrary, probably due to the concentration of financial services and corporate headquarters in the Portuguese capital city compared to the rest of the country, location in the district of Lisbon does not affect the odds of switching to another bank. In contrast, it is a significant determinant of the propensity to move outside the banking industry. Eventually, in line with the findings in the past literature, top manager, manager and professional positions display the highest propensity to firm switch.

12 Our figures are much higher than those reported, for instance, by Larsson (2003), who calculates correct classification rates between $6.8 \%$ and $76.1 \%$.

DINÂMIA'CET - IUL, Centro de Estudos sobre a Mudança Socioeconómica e o Território 
Table 6. The drivers of propensity to firm and industry change

\begin{tabular}{|c|c|c|c|c|c|c|c|c|c|}
\hline & \multicolumn{3}{|c|}{ Move to banking } & \multicolumn{3}{|c|}{ Move to finance } & \multicolumn{3}{|c|}{ Move outside finance } \\
\hline & $\beta$ & $\begin{array}{l}\text { Std. } \\
\text { Error }\end{array}$ & & $\beta$ & $\begin{array}{l}\text { Std. } \\
\text { Error }\end{array}$ & & $\beta$ & $\begin{array}{l}\text { Std. } \\
\text { Error }\end{array}$ & \\
\hline Constant & 24.030 & 0.510 & $* * *$ & 11.804 & 1.058 & $* * *$ & 12.418 & 1.176 & $* * *$ \\
\hline Turnover t0 & -0.068 & 0.132 & & 0.806 & 0.275 & $* * *$ & -0.069 & 0.274 & \\
\hline Tenure t0 & -0.027 & 0.012 & $* *$ & -0.156 & 0.024 & $* * *$ & -0.101 & 0.023 & $* * *$ \\
\hline Squared tenure t0 & -0.005 & 0.001 & $* * *$ & 0.000 & 0.001 & & 0.001 & 0.001 & \\
\hline Education years t0 & 0.023 & 0.010 & $* *$ & 0.028 & 0.020 & & 0.041 & 0.022 & $*$ \\
\hline Age hire t0 & -0.112 & 0.004 & $* * *$ & -0.068 & 0.008 & $* * *$ & -0.087 & 0.009 & $* * *$ \\
\hline Ln firm size to & 0.060 & 0.015 & $* * *$ & -0.023 & 0.029 & & -0.046 & 0.034 & \\
\hline Ln dwage peers & 0.245 & 0.095 & $* * *$ & -0.149 & 0.196 & & 0.074 & 0.208 & \\
\hline Attractiveness & 0.037 & 0.834 & & 33.336 & 1.012 & $* * *$ & 28.833 & 1.061 & $* * *$ \\
\hline Gender $^{(a)}$ & -0.335 & 0.049 & $* * *$ & 0.046 & 0.100 & & -0.380 & 0.111 & $* * *$ \\
\hline Lisbon & -0.052 & 0.047 & & 0.512 & 0.106 & $* * *$ & 1.041 & 0.119 & $* * *$ \\
\hline Manager $\mathrm{t} 0^{(\mathrm{b})}$ & 0.376 & 0.083 & $* * *$ & -0.683 & 0.176 & $* * *$ & -0.422 & 0.186 & $* *$ \\
\hline Supervisor $\mathrm{t}^{(\mathrm{b})}$ & 0.210 & 0.145 & & -0.878 & 0.332 & $* * *$ & -0.748 & 0.453 & $*$ \\
\hline Professional $\mathrm{t} 0^{(\mathrm{b})}$ & 0.366 & 0.077 & $* * *$ & -0.575 & 0.144 & $* * *$ & -0.202 & 0.156 & \\
\hline Qualified $\mathrm{t} 0^{(\mathrm{b})}$ & 0.015 & 0.082 & & -0.810 & 0.158 & $* * *$ & -0.269 & 0.165 & $*$ \\
\hline Semiqualified $\mathrm{t} 0^{(\mathrm{b})}$ & -0.115 & 0.131 & & -1.004 & 0.358 & $* * *$ & -1.498 & 0.441 & $* * *$ \\
\hline -2 Log likelihood & 20.666 .10 & & & & & & & & \\
\hline Nagelkerke R Square & 0.590 & & & & & & & & \\
\hline
\end{tabular}

(a) Reference category: male employees. (b)Reference category: Top managers

Table 7. Predictive power of the multinomial logit model

\begin{tabular}{lrrrrr}
\hline & \multicolumn{5}{c}{ Predicted } \\
Firm & $\begin{array}{c}\text { Move to } \\
\text { banking }\end{array}$ & $\begin{array}{l}\text { Move to } \\
\text { finance }\end{array}$ & $\begin{array}{c}\text { Move outside } \\
\text { finance }\end{array}$ & $\begin{array}{c}\text { Percent } \\
\text { Correct }\end{array}$ \\
\hline Firm stayers & 41.139 & 926 & 11 & 0 & $97.8 \%$ \\
Move to banking & 2.077 & 1.501 & 4 & 0 & $41.9 \%$ \\
Move to finance & 225 & 73 & 696 & 18 & $68.8 \%$ \\
Move outside finance & 257 & 55 & 83 & 80 & $16.8 \%$ \\
\hline
\end{tabular}

Table 8 reports the difference-in-differences estimates of the return to firm mobility calculated according to formula (5) in section 3 in case of binary treatment and to formula (4) for multilevel treatment. All standard errors are bootstrapped with 500 repetitions. The first panel of Table 8 shows that after controlling for pre-treatment differences and for individual unobserved heterogeneity firm switchers still benefit from a significant wage increase compared to firm 
stayers. However, when the average treatment on the treated accounts for the destination industry (second panel of Table 8 ) it becomes apparent that the overall picture is the sum of significantly segmented patterns. On average, movers to other retail banks benefit from the highest wage increase compared to the counterfactual group of firm stayers. A significant relative wage increase also accrues to workers who move to a new employer in the financial industry, despite the size of the benefit is less than one third compared to firm switchers who remained in the banking industry. Eventually, the wage growth displayed by employees who move outside the banking and the finance sector does not significantly differ from that of comparable individuals who remain with their original employer.

The results displayed in Table 8 provide substantial support to the hypothesis of skill transferability from the banking sector. Also when moving to employers in markedly distant sectors, the skills provided by former bank employees are valued by their new employers and, at least in the short run, their wage dynamics do not display significant differences compared to the option of remaining with the original employer. At the same time, the decline in the advantage perceived by firm switchers with the distance of the destination industry from the banking sector confirms that the observed employees sell transferable rather than general skills to their new employers. Recruiting from a competitor means saving in formal and informal training for banking firms that are willing to pay a wage differential to attract readily-operative employees. However, the re-usability of skills quickly declines as banking employees move to industries characterised by more diversified outputs and processes.

Table 8. The return to firm mobility - PDM-DID estimates of wage increase

\begin{tabular}{|c|c|c|c|c|}
\hline & $\begin{array}{c}\text { Differential total } \\
\text { gross hourly wage }\end{array}$ & $\begin{array}{c}\text { Bootstrap std. } \\
\text { error } \\
\end{array}$ & $\mathrm{z}$ & \\
\hline \multicolumn{5}{|l|}{ Binary treatment } \\
\hline Firm switchers vs. Firm stayers & 1.094 & 0.070 & 15.57 & $* * *$ \\
\hline \multicolumn{5}{|l|}{ Multi-level treatment } \\
\hline Movers to banking vs. Firm stayers & 1.433 & 0.083 & 17.33 & $* * *$ \\
\hline Movers to finance vs. Firm stayers & 0.446 & 0.106 & 4.19 & $* * *$ \\
\hline Movers outside finance vs. Firm stayers & 0.299 & 0.220 & 1.36 & \\
\hline
\end{tabular}

47.245 observations; $* * * p<0.01$; Deflated gross hourly wages $(\epsilon$. base $=1992)$ 


\section{CONCLUDING REMARKS}

Increasing job volatility, rising training costs and more frequent organisation and technological change focus the attention of labour market players on transferable skills. Transferable skills increase workers' employability and provide firms with ready-to-use competences and capabilities to fill up opening and vacant positions. Assuming that transferable skills will be signalled by a non-negative wage progression of firm switchers compared to firm stayers. this paper tested the borders of transferability for the skills developed within a sector traditionally described as a collection of internal labour markets characterised by firm-specific skills, i.e., retail banking.

Contrary to the prevailing approach in the literature for appraising the return to interindustry mobility, we claim that the distance between source and destination sectors matters. The larger the difference in technologies, techniques and labour flow organisation between the source and the destination industry, the lower the probability of inter-industry skill transfer. We account for the distance between source and destination sector by modelling firm change as a multi-level treatment whose intensity increases with the distance between the banking industry and the sector where firm switchers find a new employment. To assess the relative wage premium of firm switchers compared to firm stayers accounting for observed and unobserved individual heterogeneity, we implemented a DID-PSM approach for a multi-level treatment. To the authors' knowledge. this paper provides the first implementation of Abadie's semi-parametric difference-in-differences PSM estimator for a multi-treatment case (Abadie, 2005).

Our empirical findings show that firm switchers benefit from mobility. On average, firm switchers enjoy a significant wage premium compared to the counterfactual group of firm stayers. However, the benefit enjoyed by employees who move to another retail bank is higher than the wage premium recognised to employees moving to finance, which in turn is larger than the benefit of moving outside the banking and finance sector. In any case, also when moving outside banking and finance, the average wage growth enjoyed by firm switchers is no lower than the wage growth experienced by firm stayers. This outcome supports the hypothesis of significant transferability of the professional skills developed within the borders of the banking sector, despite declining with the distance from the original industry.

In general terms, our results question the traditional vision of retail banking as a source of industry-specific, if not firm-specific, skills. The provided output rather depicts banking as a training sector for transferable skills and a potential skill supplier for the whole economy. However, the small figures concerning firm switchers and industry switchers $(10.8 \%$ and $3.1 \%$ of total observations, respectively) command some caution in extending and generalising our results. In case of increased competitiveness of internal and external labour markets in the bank- 
ing industries, competing banks and non-banking firms may be unable to absorb all firm leavers, thus frustrating their investment in transferable skills. At the same time, higher turnover and quit rates may induce banking firms to review their internal training policy and turn to external sourcing to fill vacant positions.

\section{Acknowledgments}

We thank the Portuguese DGEEP - Ministry of Labour and Social Security for access to Quadros the Pessoal. We are also grateful to DGEEP staff for additional information on the dataset. Financial support from FLEX FCT grant PTDC/EGE-ECO/108547/2008 and Fondo di Ateneo ex-60\% UniBS is gratefully acknowledged.

\section{REFERENCES}

ABADIE, A. (2005), "Semiparametric Difference-in-Differences Estimators", Review of Economic Studies, n. ${ }^{-}$72, pp.1-19.

ACT (2005), "ACT entre várias instituições de crédito e o Sindicatos dos Bancários do Norte e outros - Alteração salarial e outras e texto consolidado", Boletim de Trabalho e Emprego, $1^{\text {a }}$ Série, n. ${ }^{\circ} 4$.

ADDISON, J.T., Portugal, P. (1989), "Job displacement, relative wage changes, and duration of unemployment", Journal of Labor Economics, VII (3), pp. 281-302.

BECKER, G. (1964), Human Capital. Chicago and London, The University of Chicago Press.

BERGEMANN, A., Fitzenbergerb, B., Speckesserf, S. (2009), "Evaluating the dynamic employment effects of training programs in East Germany using conditional difference-indifferences", Journal Of Applied Econometrics, n. ${ }^{2} 24$, pp.797-823.

BLUNDELL, R., Costa Dias, M. (2000), "Evaluation Methods for Non-Experimental Data", Fiscal Studies, XXI (4), pp.427-468.

BLUNDELL, R., Costa Dias, M., Meghir, C., Van Reenen, J. (2004), "Evaluating the employment impact of a mandatory job search program", Journal of the European Economic Association, II (4), pp.569-606. 
BOYCE, C., Brown, G., Moore, S. (2010), "Money and happiness: rank of income, not income, affects life satisfaction", Psychological Science, XXI (4), pp.471-475.

BUSCHA, F., Maurel, A., Page, L., Speckesser, S. (2012), "The Effect of Employment while in High School on Educational Attainment: A Conditional Difference-in-Differences Approach,” Oxford Bulletin of Economics and Statistics, LXXIV (3), pp.380-396.

BUZZACCHI, L., Colombo, M., Mariotti, S. (1995), "Technological regimes and innovation in services: The case of the Italian banking industry", Research Policy, n.ํㅜ 24, pp.151-168.

CALIENDO, M., Kopeinig, S. (2008), "Some practical guidance for the implementation of PSM", Journal of Economic Survey, XXII (1), pp.31-72.

CARDOSO, A.R., Portugal, P. (2005), "Contractual Wages and the Wage Cushion under Different Bargaining Settings”, Journal of Labor Economics, XXIII (4), pp.875-901.

CHA, Y., Morgan, S.L. (2010), "Structural earnings losses and between-industry mobility of displaced workers, 2003-2008”, Social Science Research, n. ํㅜ 39, pp.1137-1152.

DAVIA, M.A. (2010), "Job mobility and wage growth at the beginning of the professional career in Spain", Revista de Economia Aplicada, XVIII (52), pp.5-34.

DOERINGER, P.B., Piore, M. (1971), Internal Labor Markets and Manpower Analysis, Lexington, Massachusetts: D.C. Heath.

DORSETT, R. (2006), "The new deal for young people: effect on the labour market status of young men”, Labour Economics, n.․ㅜ 13, pp.405-422.

ERIKSSON, T., Werwatz, A. (2005), “The Prevalence of Internal Labour Markets - New Evidence from Panel Data", International Journal of Economics Research, n. ${ }^{\circ}$, pp.1-20.

ESTEVES, M.T. (2008), Práticas de Gestão de Recursos Humanos e Atitudes e Comportamentos de Trabalho: Estudo de Caso no Sector Bancário Português, PhD Thesis, ISCTE.

FAIRRIS, D. (2004), “Internal labor markets and worker quits”, Industrial Relations, XLIII (3), pp.573-593. 
GATHMANN, C., Schönberg, U. (2007), "How General Is Human Capital? A Task-Based Approach”, IZA, Bonn, Discussion Paper n.ํㅜ 3067.

GELADE, G.A., Ivery, M. (2003), "The impact of human resource management and work climate on organizational performance", Personnel Psychology, LVI (2), pp.383-404.

HECKMAN, J.J., Ichimura, H., Todd P.E. (1997) "Matching as an Econometric Evaluation Estimator: Evidence from Evaluating a Job Training Programme", Review of Economic Studies, LXIV (4), pp.605-54.

HUNTER, L.W., Bernhardt, A., Hughes, K.L., Skuratowicz, E. (2001). "It's not Just the ATMs: Technology, Firm Strategies, Jobs and Earnings in Retail Banking”. Industrial and Labor Relations Review. LIV (2A), pp.402-424.

IMBENS, G.W.,Wooldridge J.M. (2009), "Recent Developments in the Econometrics of Program Evaluation", Journal of Economic Literature, XLVII (1), pp.5-86.

KAMBOUROV, G., Manovskii, I. (2009), “Occupational Specificity of Human Capital”, International Economic Review, L (1), pp.63-115.

KLETZER, L.G. (1996), "The role of sector-specific skills in postdisplacement earnings", Industrial Relations, XXXV (4), pp.473-490.

LARSSON, L. (2003), "Evaluation of Swedish Youth Labor Market Programs", The Journal of Human Resources, XXXVIII (4), pp.891-927.

LAZEAR, E.P. (2003), "Firm-Specific Human Capital: A Skill-Weights Approach", NBER Working Paper n. ${ }^{\circ} 9679$.

LECHNER, M. (2001), "Identification and estimation of causal effects of multiple treatments under the conditional independence assumption", in M. Lechner, F. Pfeiffer (eds) Econometric Evaluation of Labour Market Policies, Heidelberg, Physica/Spring, pp.43-58.

LEOMBRUNI, R., Razzolini, T., Serti, F. (2010), "The pecuniary and non-pecuniary costs of job displacement. The risky job of getting back to work", paper presented at 9th IZA/SOLE Transatlantic Meeting of Labor Economists, Buch/Ammersee, Germany, 27-30 May. 
MAMEDE, R. (2006), "Labour Mobility and Firm Survival”, paper presented at Workshop Quadros de Pessoal e Investigação em Economia, University of Minho, Portugal, 15 September.

MONTEIRO, N.P. (2009), "Regulatory reform and labour earnings in Portuguese banking", Empirical Economics, n. ${ }^{\circ}$ 36, pp.557-574.

NEAL, D. (1995), "Industry-specific human capital: evidence from displaced workers", Journal of Labor Economics, XIII (4), pp.653-677.

ONG, P., Mar, D. (1992), "Post-Layoff Earnings Among Semiconductor Workers", Industrial and Labor Relations Review, XLV (2), pp.366-379.

PACK, H., Paxson, C. H., (1999), "Inter-industry labor mobility in Taiwan, China", The World Bank, Policy Research Working Paper Series, n. ${ }^{\circ} 2154$.

PARENT, D. (2000), "Industry-specific capital and the wage profile: evidence from National Longitudinal survey of Youth and the Panel Study of Income Dynamics", Journal of Labor Economics, XVIII (2), pp.306-323.

PODGURSKY, M., Swaim, P. (1987), "Job displacement and earnings loss: evidence from the displaced worker survey", Industrial and Labor Relations Review, XLI (1), pp.17-29.

POLETAEV, M., Robinson, C. (2008), "Human Capital Specificity: Evidence from the Dictionary of Occupational Titles and Displaced Worker Surveys, 1984-2000", Journal of Labor Economics, XXVI (3), pp.387-420.

POSCHL, J., Foster, N. (2010), "The importance of labour mobility for spillovers across industries", Working Paper Micro-Dyn n.․ำ 29/10.

ROSENBAUM, P.M., Rubin, D.B. (1983), “The Central Role of the Propensity Score in Observational Studies for Causal Effects", Biometrika, LXX (1), pp.41-55.

SELTZER, A. (2010), "Salaries and promotion opportunities in the English banking industry", 1890-1936, Business History, LII (5), pp.737-759. 
SELTZER, A.J., Frank, J. (2007), "Promotion tournaments and white collar careers: evidence from Williams Deacon Bank, 1890-1941”, Oxford Economic Papers, LIX (Supplement: New Perspectives in Economic History), pp.i49-i72.

SELTZER, A., Merrett, D. (2000), "Personnel Policies at the Union Bank of Australia: Evidence from 1888-1900 Entry Cohorts”, Journal of Labor Economics, XVIII (4), pp.573-613.

SHAW, K.L. (1987), "Occupational Change, Employer Change, and the Transferability of Skills”, Southern Economic Journal, LIII (3), pp.702-719.

SILVA, T.F. (2009), Concentração Bancária em Portugal, Master Thesis, ISCTE.

SPENCE, M. (1973), "Job market signalling”, Quarterly Journal of Economics, LXXXVII (3), pp.355-374.

STEVENS, M. (1996), "Transferable Training and Poaching Externalities", in A. Booth, J. Snowers (eds.), Acquiring Skills. Market Failures, their Symptoms and Policy Responses, Cambridge, University Press, pp.19-40.

SULLIVAN, P. (2010), "Empirical evidence on occupation and industry specific human capital", Labour Economics, XVII (3), pp.567-580.

WEINBERG, B.A. (2001), "Long-term wage fluctuations with industry-specific human capital”, Journal of Labor Economics, XIX (1), pp.231-264.

ZANGELIDIS, A. (2008), "Occupational and Industry Specificity of Human Capital in the British Labour Market”, Scottish Journal of Political Economy, LV (4), pp.420-443. 